\title{
Noun Phrase In Minang Language
}

\author{
Akmal $^{1} \&$ Jamaluddin Nasution ${ }^{2}$ \\ Sekolah Tinggi Manajemen Informatika dan Komputer Royal Kisaran ${ }^{1}$ \\ Universitas Prima Indonesia ${ }^{2}$ \\ Jl. Prof. H.M.Yamin No.173 Kisaran¹ .

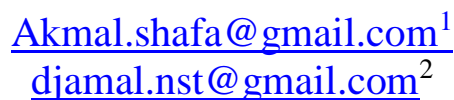

Received: 04 March 2021; Revised: 26 April 2021; Accepted: 28 July 2021

DOI: http://dx.doi.org/10.37905/aksara.7.3.1077-1086.2021

\begin{abstract}
Phrase structure rules express the basic structural facts of the language in the form of "phrase markers". This study discussed about the noun phrase in Minangkabau Language. The aim of this study is to find out the noun phrases of Minangkabau Language and how the noun phrases are used in the language. The used method is qualitative research design by interviewing the native speakers of Minangkabau by using the depth interview. the participants are the people who lived in Sukaramai Districts. They were born in Pariaman Districts and they are educated people who understand about the phrase structure.The researcher described the finding data more details. In this study, there are six noun phrase forms in Minangkabau Language and there is one unique form. The noun phrases are implicated in the daily activity of society. In fact, there was a unique noun phrase in Minang Language namely: Noun Phrase (NP) is $\mathrm{N} 1+\mathrm{sa}+\mathrm{N} 2$.
\end{abstract}

Keywords: phrase structure, noun phrase.

\section{INTRODUCTION}

There were some previous studies about the phrase stucture in a few specific languages in Indonesia such as Kodeoha Language, Manggarai Language, Talondo Language. The study of Kodeoha Language (KL) discussed about the special nouns in the phrase structure. Manggarai Language (ML) discussed about the inflectional phrase in the phrase structure. Tolonto Language (TL) study discussed about the structure of phrases, clauses, and sentences of the Talondo Language (Kurniawati, 2020; R, 1985; Umiyati \& Kosmas, 2010).

Minangkabau Language is nearly same to the Indonesian Language. Minangkabau Language is a language which is used by most of West Sumatera people and by many other people who live in other regions either the people of Minang lived in West Sumatera or the people of Minang lived in other provinces in Indonesia. Minang Language had different dialects and it was happened because of places (areas), the speech functions, and the social factor of speech functions. The little differences were between one area and another area, it was called the dialect (Lindawati, 2015).

In this study, the researcher found out what the phrases structures in Minangkabau Language (ML) especially in the noun phrase. The problems of this study is a little more specific than the previous researches about the phrase structures in the syntax study. In 
using this study, the researcher applied the Transformational Grammar (TG) by Noam Chomsky as the first expert of TG. In this theory, Transformational Grammar s model of syntax consisted of two rule systems: phrase structure rules and transformations. Phrase structure rules generated a constituent structure for the sentence into which words were inserted and now it is called by Transformational Generative Grammar's model of Syntax. In this study, the researcher described the noun phrase in the phrase structures in Minangkabau Language. In this study, the researcher also used the X-Bar theory in analysis of Generative Grammar's model of Syntax because the theory of X-Bar made the analysis more clearly and to make it more simply.

The term of phrase is used in a somewhat different way from the so-far accepted idea that it is always a group of words. A noun phrase is something built around a noun. A pronoun because of its capacity of representing a noun and a relative clause together with its noun head, it can be said and it can be called a noun phrase (NP). This applies to other four phrases. a noun phrase may consist of a noun and a prepositional phrase and the prepositional phrase consisted of a preposition and another noun phrase, which consisted of a determiner and a noun. Noun phrase could be a single word of a noun or more than one word of noun (JapenSarage, 2014).

$\mathrm{Ba}^{\mathrm{ee}}$ dulu (2008:40) stated that the English syntax is one of the important subjects that the students need to understand in the language studies. Syntax is a part of structural linguistics. the mastery of syntax makes the students have capability to speak and write English accurately. Its areas cover the English phrases and clauses. The English phrases have some various divisions, such as Noun Phrase (NP), Verb Phrase (VP), Adjective Phrase (Adj P), Adverb Phrase (Adv P), and Prepositional Phrase (Prep P). Syntax is also frequently considered as a mathematic subject because it contains analyses. The wellknown analyses are bracketed, immediate constituent, and tree diagram analyses (Junaid, 2018).

Phrase structure rules express the basic structural facts of the language in the form of "phrase markers" they generate, 1 with terminal strings drawn from the lexicon. In particular, phrase markers generated by phrase structure rules express three kinds of information about syntactic representations: 1). the hierarchical grouping of the "constituents" of the structure (Dominance); 2). the "type" of each constituent (Labeling); and 3). the left-to-right order (linear order) of the constituents (Precedence). For example, the phrase marker (3), generated by the phrase structure rules in (4), indicates that the largest constituent, whose label is $\mathrm{S}$ (the designated initial symbol), is made up of a constituent NP (Noun Phrase) preceding the other constituent VP (Verb Phrase); that the NP consists of two constituents, D(eterminer) and a N(oun), in this order; and that the VP is composed of V(erb) and NP (in this order), and so on (Fukui, 2018).

In the Syntactic Structures, Chomsky has presented a theory of phrase structure comprising phrase structure rules, which were the part of so-called base component, and transformations, which formed the transformational component. There was no separate lexicon - terminals of phrase markers (the actual words and morphemes) were assumed to be introduced by Phrase Structure's (PS) rules in the same way that non-terminal nodes of the syntactic representations were. The Phrase Structure's (PS) rule system persisted until well into the 1970s, though their perview was reduced in Chomsky (1965) by the introduction of the lexicon, so that lexical items were no longer need to be introduced by (PS)-rules. PS-rules eventually gave way, however, to the desire to capture the 
fundamental endocentricity of syntactic structures in a formally explicit way. The advent of X-bar Theory (Chomsky 1970a, Jackendoff 1977; see esp. Chapter 11, this volume) (Dikken, 2013).

X-Bar theory has been developed Chomsky to know the formation of phrases and it had a universal value. X-Bar theory could be used by any languages, it includes Arabic Language and English Language. According to Dwijatmoko (2002) stated that in X-bar theory, one rule that should be followed is that the a syntactic unit which is used is either head or phrase and phrase is the maximal projection or the biggest chunk of category (Wittaningsih, 2018). X-bar theory is discussed in almost all modern textbooks of syntax, and it is routinely assumed as a theory of phrase structure in a variety of otherwise widely differing schools of grammatical thought such as government-binding theory (GB), lexical-functional grammar (LFG), and generalized phrase structure grammar (GPSG). According to Stowell (1981) explained that by embodying substantive principles of phrase structure, X-bar theory should narrow down the range of choices to a small, preferably universal set of possible analyses. A maximally strong version of X-bar theory would in fact narrow down the set of possible choices to one, and would thereby eliminate the need for language-specific phrase structure rules in the manner suggested (Kornai \& Pullum, 1990).

Bar-level was originated as a notation for phrasal category labels that made it more clearly how they were based on the lexical category labels. Thus, in a complex noun phrase like [a [[student] [of linguistics]]], the head noun student might be labeled $\mathrm{N}$ (with bar-level zero), the noun-plus-complement group student of linguistics might be labeled $\mathrm{N}^{\prime}$ (with bar-level one; primes are used instead of overbars for typographical convenience), and the full phrase a student of linguistics might be labeled N" (with barlevel two).

\section{METHODS}

\subsection{Research Design}

In this study, the researcher used the qualitative research design. Qualitative research dealed with gathering and interpretation of non-numerical data especially for the purpose of understanding human and social environment in the reality of life (Adedoyin, 2020). Qualitative research was to gain insights into these constructions of reality, i.e., to tease out the nature of the world as it was experienced, structured and interpreted by people in the course of their everyday lived. The information of qualitative, the researcher collected in order to gain the necessary insights was largely, although not always, obtained by means of the narratives in which the people being studied to communicate the way they understood the world. This involved most obviously speaking, but it could involve other forms of the communication such as diaries, the literary or library audio or video tapes, or artworks, or even result from close and systematic observation of people going about their lives in their usual manner. It is common for narratives to involve interviews although this is not necessarily the case (Cropley, 2019).

Besides that, the researcher used the X-Bar theory to analyze the phrase structure especially in noun phrase of Minangkabau Language. Accoding toNapoli (1996:305) in Mulyadi (2008) stated that in X-Bar theory, all phrases have a lexical core. The core was the last symbol which dominated the word, or the lexical projection of a word category. The core had the property as following. First, the core marked the characteristics of its 
category. For example, the core of NP was N, the core of AP was A, the core of VP was $\mathrm{V}$, and so on. Secondly, the core was put one lower level in X-Bar hierarchy than the constituent core.the core category had empty bar or it could be said without a bar (Mulyadi, 2008).

\subsection{Participants}

The participants of this study were the Minangkabau people who lived in Sukaramai and they also have understood about the phrase structure in Indonesian Language and Minangkabau Language because they have had high education and they were born in Pariaman District of West Sumatera. The researcher interviewed a few educated people in the phrase of Minangkabau Language after he read the documents about the Minang Language's phrase structure especially in noun phrase. The researcher just interviewed the people who knew and understood about the structure of Minangkabau Language because not all native speakers could understand about the structures of the language. The researcher has chosen the participants because they have learnt the structure in Indonesia so they knew how the process of structure in Minangkabau Language.

\subsection{Data Collection Tools}

In this study, the researcher used the depth interview to get the data from the people who really understood Minangkabau Language based on the structures of Minangkabau especially the noun phrase in the phrase structure of Minangkabau. The researcher gave the questions based on the problems of this study whether the form of noun phrases were and how the form of noun phrases were in Minangkabau Language Structure. He would save the informations from the participants who have told about the noun phrases so that he got the real data findings and discussions.

\subsection{Data Collection}

In this study, the researcher took the data collection as follow:

a. The researcher read the digital books or journals about the phrase structures especially about the noun phrase so that the researcher has knowledge more deeply about it.

b. The researcher also found out the noun phrase of Minangkabau Language on the digital structures book.

c. After getting the both previous, the researcher collected the phrase structure data of Minangkabau Language by interviewing a few of educated people who knew about the noun phrases and recording the results of interview.

\subsection{Data Analysis}

In this study, the researcher took the data analysis as follow:

a. After the data were collected either from the digital or from the interview, the researcher began to analyze the noun phrases of Minangkabau Language structures.

b. The researcher comprehend the theory to analyze the phrases one by one so that the analysis would get the best analysis

c. Then the researcher got the kind of noun phrase in Minangkabau Language structures and describe the findings of research more details. 


\section{RESULTS AND DISCUSSIONS \\ Results}

In this study, the researcher has got the findings of data in noun phrase of Minangkabau Language. The pattern of noun phrase in Minangkabau as the following table

Table.1: data of Noun Phrase in Minangkabau Language Structures

\begin{tabular}{|c|c|c|}
\hline Patterns of Noun Phrase & $\begin{array}{l}\text { English Language } \\
\text { Examples }\end{array}$ & $\begin{array}{c}\text { Minangkabau Language } \\
\text { Examples }\end{array}$ \\
\hline \multirow{3}{*}{ 1. $\mathrm{NP}: \mathrm{N} 1+\mathrm{N} 2$} & Iron car & mboil besi \\
\hline & Book store & Kadai buku \\
\hline & mirror glass & Galeh kaco \\
\hline \multirow[t]{2}{*}{ 2. NP : N1 + V } & Work room & Ruang karajo \\
\hline & Butcher & Tukang bantai \\
\hline \multirow[t]{2}{*}{ 3. $\mathrm{NP}: \mathrm{N} 1+\mathrm{sa}+\mathrm{N} 2$} & A room mate & Kawan sakamar \\
\hline & A same country person & Urang sanagari \\
\hline \multirow[t]{2}{*}{ 4. NP : N1 + Adj. } & Dirty book & Buku koto \\
\hline & Big house & Rumah gadang \\
\hline \multirow{2}{*}{$\begin{array}{l}\text { 5. NP : } \\
\text { Demonstrative }\end{array}$} & This house & rumah ko \\
\hline & That house & rumah tu \\
\hline \multirow[t]{2}{*}{ 6. NP : NP + F prep. } & Money on the table & Pitih di ateh meja \\
\hline & A girl at the market & Padusi di pasa \\
\hline
\end{tabular}

\section{Discussions}

After the researcher took and got the finding data, he interviewed the paricipants more details about the noun phrase so that the data could be described or elaborated them one by one. In their explanations that noun phrase was a modicative phrase which had a heading noun was added other elements. Other elements could be noun phrase categories, such as noun + adjectives, noun + verbs, noun + demonstratives, noun + numbers, noun + prepositions. Then the noun phrase is Noun1, and noun $+\mathrm{sa}+$ Noun2. The noun phrase could function as a subject, an object, and a complement of constructive predicate. Then they could be described as follows:

1. Noun Phrase (NP) is Noun1(N1) + Noun2 (N2).

1a. mobil besi

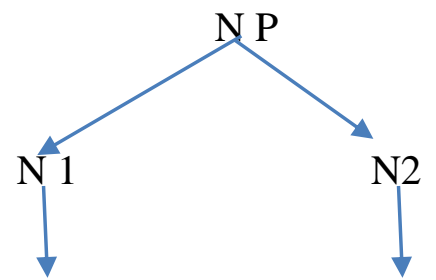

Note:

mobil (car)

besi (iron)

$\mathrm{NP}=\mathrm{N} 1+\mathrm{N} 2$

$\mathrm{N} 1=$ mobil (car)

$\mathrm{N} 2=$ besi (iron) 
1b. Toko Buku

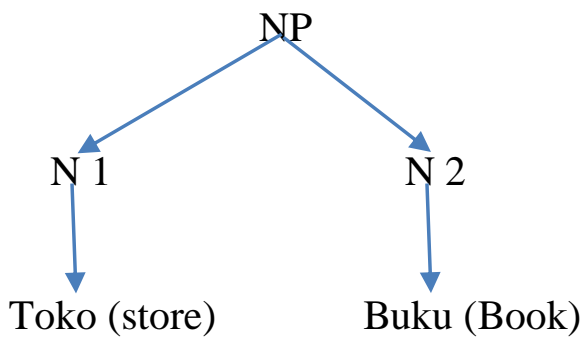

Note:

$\mathrm{NP}=\mathrm{N} 1+\mathrm{N} 2$

$\mathrm{N} 1=$ Toko

$\mathrm{N} 2=\mathrm{Buku}$

2. Noun Phrase (NP) is Nounl (N1) + Verb (V)

The relationships were between noun and verb which attributed to be function or profession.

Examples: 2a. Ruang karajo (the working room)

$2 b$. Tukang bantai (the butcher)

The four examples of noun phrases above, the noun phrases b1 was to describe function whereas: 2a was the room functions to work. Then the noun phrases $2 \mathrm{~b}$ was to describe profession whose profession is cutting animal and b4 was someone whose profession is cutting the hair.

Examples:

2a. Ruang karajo

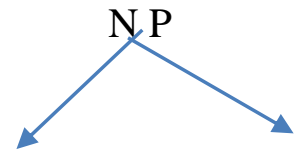

V

bantai

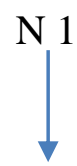

Ruang 2b. Tukang bantai
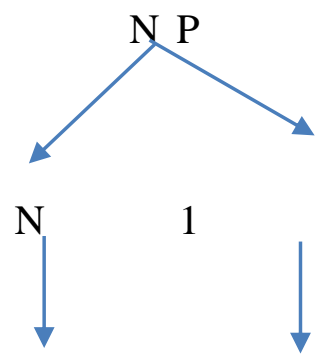

Tukang

Note:

Note:

2a. $\mathrm{NP}=\mathrm{N} 1+\mathrm{V}$

$\mathrm{N} 1$ = Ruang

2b. $\mathrm{NP}=\mathrm{N} 1+\mathrm{V}$

$\mathrm{V}=$ karajo

$\mathrm{N} 1=$ Tukang

$\mathrm{V}=$ bantai 
3. Noun Phrase (NP) is Noun1 (N1) + sa + Noun2 (N2)

The words which were followed by $s a$ were the words which were to describe measuring and grouping. In Minangkabau Language, it had many kinds of terms which were used to describe the measuring of any things. The measuring depended on the kind of goods and it was related to the substance properties and form of the goods. For liquid objects such as oil and water, for example, the solution was in the form of a vessel or scale. So it was so clear the form of Noun Phrase (NP) is from Noun1 (N1) was added the word $\boldsymbol{s} \boldsymbol{a}$ and it was added Noun2 (N2). The word $\boldsymbol{s} \boldsymbol{a}$ was so specific in Minang Language Structures.

Examples: 3a. Aie sagaleh ( a glass of water)

3b. Minyak sakilo ( a kilogram of oil)

The three examples of noun phrases above that noun phrase of $\mathrm{c} 1$ was a measuring of water to drink, it was given by the symbol of glass as a measurement of drink water. The noun phrase of $\mathrm{c} 2$ was cooked oil which was always mentioned by calling a kilogram to make a measuring of oil

3a. Aie sa galeh
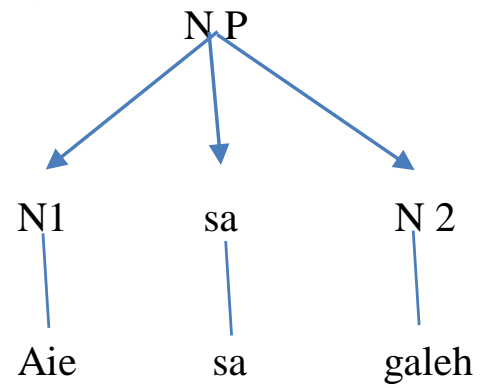

Note:

$\mathrm{NP}=\mathrm{N} 1+\mathrm{sa}+\mathrm{N} 2$

$\mathrm{N} 1=$ aie

$\mathrm{Sa}=\mathrm{sa}$

$\mathrm{N} 2$ = galeh

3b. minyak sakilo

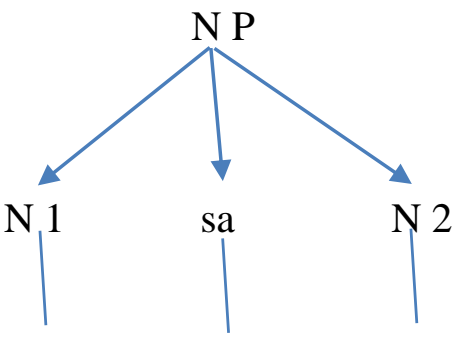

Note:

Minyak sa kilo

$\mathrm{NP}=\mathrm{N} 1+\mathrm{sa}+\mathrm{N} 2$

$\mathrm{N} 1=$ minyak

$\mathrm{Sa}=\mathrm{sa}$

$\mathrm{N} 2=$ kilo 


\section{Noun Phrase (NP) is Nounl (N1) + Adjective}

The adjective which followed the noun phrase is to show the quality of goods. For some goods, there were perhaps different goods, but they used the same adjective to make a noun phrase. It could be seen the examples below:

Examples: 4a. Urang gapuak/urang taba (fat person)

4b. Buku taba (thick book)

From the two examples of noun phrases, it could be explained that the noun phrase of $4 a$ was the word of taba same meaning to gapuak. Some people of Minangkabau expressed the word of taba to show the adjective gapuak. The noun phrase of $4 b$ was so suitable in used to express about the book pieces which perhaps it was thick.

4a. urang gapuak

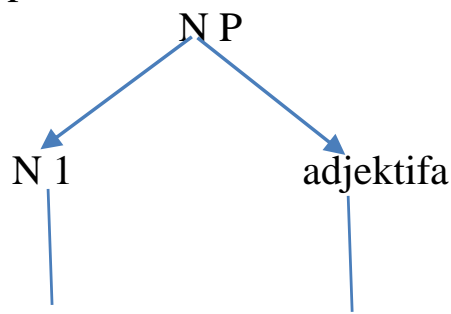

Urang gapuak

Note:

$\mathrm{NP}=\mathrm{N} 1+$ Adjektifa

$\mathrm{N} 1=$ urang

Adj = gapuak

5. Noun Phrase (NP) is Noun Phrase (NP) + Demonstrative (Demons)

In this noun phrase, there was nothing explanation because it was so clear and not so important to elaborate. It could be seen the example below:

Examples: 5a. Buku ko (this book)

5b. Buku tu (that book)

5a. buku ko

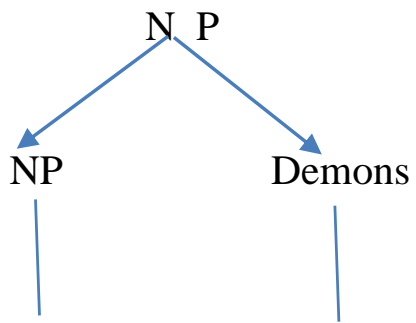

Buku ko

Note:

$\mathrm{NP}=\mathrm{NP}+$ Demons

$\mathrm{NP}=$ buku

Demon $=\mathrm{ko}$ 
6. Noun Phrase (NP) is Noun Phrase (NP) + Prep. Phrase (PP) + Noun Phrase (NP) In this noun phrase, there was also nothing explanation because it was so clear the meaning of noun phrase. It could be seen the examples below:

Examples: 6a. Pitih di meja (money on the table)

$6 b$. gadih di ateh pasa (a girl at the market)

6a. pitih di ateh meja

Note:

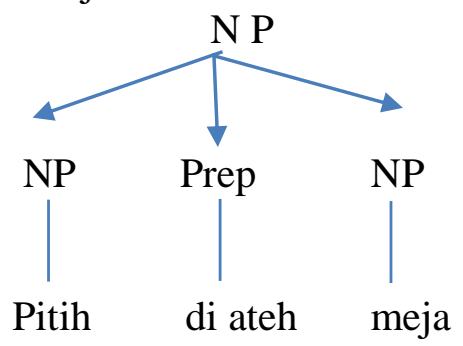

$\mathrm{NP}=\mathrm{NP}+$ Prep $+\mathrm{NP}$

$\mathrm{NP}=$ pitih

Prep $=$ di ateh

$\mathrm{NP}=$ meja

\section{CONCLUSIONS}

After getting the results and discussions, it concluded that:

a. The term of phrase is used in a somewhat different way from the so-far accepted idea that it is always a group of words. A noun phrase is something built around a noun. There were some forms of noun phrases in Minangkabau Language.

b. In Minangkabau language, there are six forms of noun phrases, namely noun phrase (Noun1 + Noun2; Noun1 + Verb; Noun1 + sa + Noun2; Noun (N) + Adjective; NP + Demonstrative; NP + Preposition Phrase). They have different meanings especially in point 1 until point 5 of noun phrases in Minangkabau Language.

c. The noun phrases in Minangkabau are unique and different with other languages especially when the noun phrase in using the daily phrases because of its cultures.

\section{References}

Adedoyin, O. B. (2020). Qualitative Research Methods. Principles of Social Psychiatry: Second Edition, 77-87. https://doi.org/10.1002/9780470684214.ch7

Cropley, A. (2019). Introduction to qualitative research methods. In A research handbook for patient and public involvement researchers. https://doi.org/10.7765/9781526136527.00012

Dikken, M. den. (2013). Generative Syntax. In International Encyclopedia of the Social \& Behavioral Sciences. Cambridge University Press. https://doi.org/10.1016/b0-08043076-7/02951-x

Fukui, N. (2018). 12 Phrase Structure. 2018, 3, 374-406.

JapenSarage. (2014). The Relationship Between Noun Phrase And Verb Phrase. ADJES

(Ahmad Dahlan Journal of English Studies), 1(1-2), 49-58. 
https://doi.org/10.26555/adjes.v1i1-2.1687

Jufrizal, Zaim, M., \& Ardi, H. (2015). STRUKTUR GRAMATIKAL DAN BUDAYA BERBAHASA : Data dan Informasi Bahasa Minangkabau.

Junaid, J. (2018). a Syntactic Analysis of the English Noun Phrase (a Study A Syntactic Analysis of The English Noun Phrase ( A Study At the Fifth Semester of English Department Faculty of Teacher Training and Education University of Muhammadiyah Makassar). Perspektif: Jurnal Pengembangan Sumber Daya Insani, 3(1), 317-326.

Kornai, A., \& Pullum, G. K. (1990). The X-bar theory of phrase structure. Language, 66(1), 24-50. https://doi.org/10.1353/lan.1990.0015

Kurniawati, W. (2020). Struktur Frasa, Klausa, Dan Kalimat Bahasa Talondo. Sirok Bastra, 8(1), 109-122. https://doi.org/10.37671/sb.v8i1.207

Lindawati. (2015). Bahasa Minangkabau. Minangkabau Press.

Mulyadi. (2008). Struktur Frasa Adjektival dalam Bahasa Indonesia. Jurnal Ilmiah Bahasa Dan Sastra, IV(1), 22-30. http://badanbahasa.kemdikbud.go.id/lamanbahasa/produk/102

R, M. (1985). Struktur Frasa Bahasa Kodeoha. Animal Reproduction Science, 9, 95-98.

Umiyati, M., \& Kosmas, J. (2010). THE INFLECTIONAL PHRASE IN MANGGARAI LANGUAGE. 147-152.

Wittaningsih, A. (2018). English Passive Voice: An X-Bar Theory Analysis. 4(2). 